\title{
Worship and Sacrifice in Isaiah 1:10-17 \\ A Textual Study and Application to the Contemporary Church and Society
}

\author{
Israel Odukogbe, PhD \\ Archbishop Vining College of Theology, \\ Oke-Emeso, Akure, Ondo State, Nigeria
}

URL:http://dx.doi.org/10.19044/esj.2020.v16n26p21

\begin{abstract}
Worship, which includes sacrifices and offerings, has been commanded by Yahweh but not as a replacement for total obedience of the Torah. However, it is common knowledge that Israel and Judah have a long biblical history of disobedience to Yahweh. Isaiah seems to visualize a mixup of blood (bull and human), which becomes a contamination before Yahweh and in turn, rendering their sacrifices worthless. This paper examines Isaiah's position alongside those of his contemporaries - Amos, Hosea and Micah through a textual study - on Yahweh's preference for obedience and social justice over empty liturgical observances. It also argues the prevalence of hypocritical services found both in Church and society today.
\end{abstract}

Keywords: Worship, obedience, corruption, church, society

\section{Introduction}

In this poetic passage, the prophetic oracle from Isaiah comes out strongly against political and religious leaders of the Eighth Century Judah. Following the usual formula "Thus says the Lord" or "Hear the word of the Lord", he commenced with the use of Sodom and Gomorrah as parallels for the wicked leaders and the led with serious indictments which shows how grievous the charges against Judah were (Holladay, 2002). When Isaiah says $h \mathrm{~h}^{\mathrm{B}} \beta \mathrm{hy}>-\mathrm{rb} ; \mathrm{d}>\mathrm{W}[\ddot{\mathrm{Im}}$. Vi (Hear the word of the Lord), he does not call attention to his own words but to what God has spoken. $r b^{\prime} \mathrm{D}^{\prime}$ (word) is a technical term for the prophetic revelation considered as absolutely authoritative, a rule of faith and practice.

Like his contemporaries (Amos, Hosea and Micah), Isaiah confronts his hearers directly and fearlessly too about the futility of their worship and various forms of sacrifice and highlights a number of important festivals that are supposed to be holy assemblies but which rather have turned to be a 
congregation whose hands are full of blood. Likewise, worship in disobedience of Yahweh's commandments is no true worship and a sacrifice offered faith is a hollow mockery. It is true Yahweh commanded sacrifice but it must come from a humble and contrite heart (Ps.51:17).

\section{Textual Background}

The first designated chapter of Isaiah consists of six originally selfcontained prophetic speeches: 1:2-3, 4-9, 10-17, 18-20, 21-26 [to which 27-28 were added], and 29-31, now fitted together to form a higher unity. It can therefore be argued that 1:2-20 is a self-contained prophetic speech composed as such from the beginning (Gitay, 1983; Roberts, 1982 and John Willis, 1984). Aside from Gitay, Roberts, and Willis, the majority of recent interpreters of Isa 1:10-17 agree that it is a sub-unit fused into a greater unity that cannot be attributed to factors like the original authorial intent.

The delimitation of a large unit of discourse and the assignment of Isa 1:10-17 to a prophet who might have delivered it before an audience goes against the consensus of contemporary scholarship. The tendency has been to discern terse prophetic sayings, sometimes no more than a biblical verse or two in length, behind the compositional unities that the text as it stands presents to us, and to assign the former to the prophet and the latter to a subsequent redactor. This is certainly so with respect to the contents of Isa 1:10-17 (Emerton, 1993).

That compositional unities are sometimes best attributed to a later redactor is undeniable. Isa 1:10-17 is part of a larger unity stretching to 1:31. It is suggested that this unity is the product of a Persian period author who added 1:27-31 to 1:21-26 and severed the latter from its original continuation preserved in 2:20 (Zvi, 2000). The collocation of 1:10-17 within a compositional unity of the Persian period implies that it was read with profit in that age, but it does not follow that 1:10-17 is itself a composition of the Persian period. The existence of compositional unities attributable to a later redactor should not deter us from seeking to identify compositional unities attributable to the prophet himself. The evidence that suggests that the book of Isaiah, as we have it, is the product of a Persian period author who reworked existing materials validates this approach.

In the context of this study, to what extent the Persian period author(s) of the book of Isaiah preserved the poetic integrity of the materials reelaborated becomes the logical question. Research covering the entire book of Isaiah, not presented in this paper, would suggest that the Persian period redactor(s) of the book of Isaiah understood and respected the prosodic conventions of the texts that lay before them, even as they reworked and expanded them for their own purposes. The atomization of 1:10-17 in any case creates more problems than it solves. 1:2-9 by itself lacks an ending and 
fails to exhibit a fully developed rhetorical intent. It is not a prophecy of doom (Fishbane, 2002,) but is chiefly retrospective in nature.

More than anything else, it raises a question: where will you be hit the next time, given your continued defiance. This is the sense of 1:5, the rhetorical peak of 1:2-9 (Wendland, 1994). The way out of the dilemma posed by 1:5 is found in 1:10-20. False solutions are dismissed first of all: a surfeit of offerings and prayer (1:11-15) will not make things right. Only the succor of society's most vulnerable members will avert a further catastrophe. This is the sense of 1:16-20, the rhetorical conclusion to the entire piece.

Similarly, if 1:10-20 is an independent unit, it is not clear why the expressions "notables of Sodom" and "people of Gomorrah" are used at its onset (1:10). As a follow up to 1:2-9, however, the sense is clear: because they just paid the price for disregard of God's expectations of them, as Sodom and Gomorrah of yore once did. There is a break between 1:2-9 and 10-20, but 1:9 provides semantic context for 1:10. The framing function of 1:2-3 and 18-20, insofar as the former calls upon heaven and earth to serve as witnesses and states the charges against the people, and the latter calls for a settlement of the case, are naturally accounted for on the hypothesis that they are design elements of a rhetorical whole so intended from the start.

Finally, 1:18-20 by itself is obscure, but 1:16-20 construed as a whole makes acceptable sense. A context-sensitive paraphrase might go like this: get your sorry offerings out of my face, cease harsh treatment of others, restrain the violent, defend orphan and widow; let's get things right; though your sins be like scarlet robes, they will become, upon fulfillment of the above demands, as white as snow. If you acquiesce and obey, you will eat of the good of the land. If not, the sword will eat you.

To Yahweh, Judah's prayers and sacrifices have become an abomination and therefore offers a remedy. It is important to note that Isaiah does not condemn sacrifices and prayers but places emphasis on social morality besides spirituality (Seltzer, 1980). Essentially in this passage, no one is exonerated of evil doing and every interpersonal relationship is to be reexamined. Similar reference to this condemnation of worship and sacrifice without righteous relationship is cited again within the book of Isaiah in 66:1 6 (Tomasino, 1996).

The central idea of this passage, therefore, is about Yahweh's loathsomeness of sacrifice and burnt-offering that is not rooted in obedience as played out in the Samuel/Saul's episode (I Sam. 15:10ff.). Here, Isaiah is not condemning a conception of God's attitude to sacrifice such as is expressed in Genesis 8:21. If these were sacrifices from penitent hearts, it would have produced sweet incense. Therefore being what they are, they became an abomination unto Yahweh. 
Apart from the book of Isaiah, the message of social justice as expressed in this passage can also be found in the books of Amos, Hosea and Micah where these prophets profoundly emphasize the defense of the weak and the less-privileged as the demonstration of the right attitude and faithfulness to the Sinai covenant. In the New Testament, Jesus describes an acceptable offering as one offered without rancor or animosity against one's neighbors (Matt.5:13ff.).

In the same vein, an unfavorable disposition toward one's neighbors is equally as bad as hands that are Wale $\left(\mathrm{m}^{\prime} \sim \mathrm{ymi} \hat{\mathrm{I}} \mathrm{D} " \sim \mathrm{k}\right.$, DydEy $>$ ("full of blood"). The hands stretched out to God in the hope of obtaining mercy had committed violent deeds. ymî̂̃" (dammim,) meaning violently shed blood, is placed before the verb in order that it becomes prominent because such blood is thought to be symbolic of unjust deeds. If the blood which fills these hands was merely that of the bull sacrifices, it would be unlikely that the hands would be so emphasized. For Isaiah the prophet, a functional interpersonal relationship becomes a fundamental prerequisite for coming into the sacred assembly where acceptable worship, prayers and sacrifices are offered.

\section{Reading through Amos, Hosea and Micah}

The key text in the oracle of prophet Amos is found in 5:21-24 which speaks expressly about Yahweh's expectations from all. He delights neither in the religious festivals nor the fat of the burnt offerings. Songs of praises and worship at holy assemblies are just like noise-making in the ears of Yahweh insofar justice does not roll down like water and righteousness like an everlasting torrent. In other words, according to Amos, Yahweh's emphasis is on right relationships among fellow humans swelling compassionately from inside and not some empty external show-off characterized by some ostentatious display of wealth and pomp which he considers a perversion of worship and sacrifice that was popular then, in the Northern Kingdom.

From this point of view, Amos' message corroborates Isaiah. In Amos 5:24 which is the climax of his oracle, $\mathrm{hq}^{\prime} \mathrm{d}^{\prime} \mathrm{C} . \quad$ ((tsedhaqah, righteousness) was closely related to $\mathrm{j}^{\prime} \mathrm{V} \cdot \mathrm{mi}$ (mishpat, justice) as expressed in Amos 5:7. Righteousness, according to Amos, is the moral posture of a man who tries to maintain a right relationship with his/her neighbors or helps to restore broken relationships. It is also the foundation of right without which there could be no mishpat (Newsome, 1984). With the introduction of 'righteousness' and 'justice', Amos gives us a setting belonging to the court of law where the village elders adjudicate legal matters in the ancient Hebrew community. 
The core idea in this disposition therefore, is that it is the responsibility of these judges to ensure that proper relations prevail with the maintenance of the social equilibrium. Topmost of these responsibilities of the judges is the task to defend, by the means of the law, those who are too poor or too weak to defend themselves. For Hosea the conditions required for restoration of proper communal relationship are more elaborate and encompassing. While Amos advocates justice and righteousness, Hosea adds steadfast love (2:19-20), faithfulness (4:1), the knowledge of Yahweh (6:6) and His mercy as part of relation building between Yahweh and Man on the one part and on the other, Man and his neighbors.

A reader of Micah who is also familiar with the book of Amos will immediately be struck by the similarity between Micah 6:6-8 and Amos 5:2124 which are, incidentally, their key texts. For the duo, the ancient Hebrew sacrificial system is not the true means of establishing a complete relationship with Yahweh. And for Micah echoing the judicial setting in Amos, Israel is summoned before Yahweh, who acts as both plaintiff and judge, to account for his long history of faithlessness in 6:1-5 allowing verses 6-8 to make a significant theological sense.

In all these, Isaiah's profound remedies in 1:16-17 to empty sacrificial routine in 1:10-15 sounds a kind of staccato in the messages of Amos, Hosea and Micah. As discussed above, Man's observation of Yahweh's command with righteousness and justice in humble service to Yahweh, living in the right relationship with his/her fellow humans is key to the unity of their theologies. In retrospect, the climax of the messages of Amos, Hosea and Micah as propounded by Isaiah is that Yahweh owns both Man and all he has given him. Therefore, Yahweh cannot be bought off or manipulated by his own gift as a substitute for the right relationships under the pretense of divine worship and sacrifice.

\section{Critical Examination}

From this passage, Isaiah seems to have visited the Jerusalem temple where people were ready to offer sacrifices and pray. This is a vivid pictorial scene of an Eighth Century aristocratic setting where the rich and the poor are gathered together and mingled, though with contrasting interests. It was a gathering of the oppressors versus the oppressed, upper versus lower class, master/slave-owner versus slaves/servants, and the rich versus the poor.

The socio-economic demands and political pressure from the upper classes of the society of that period was simply unbearable on the less privileged. Somehow the general exertion of state taxation and forced labor became a mechanism of oppression on the small farmers under this difficult economic condition (Mic. 3:10, Hab. 2:12, Jer. 22:13-17). According to R. Albertz (1994), the harsh ancient law of credit was the main instrument in this 
process of economic repression. The reason was that it enabled the creditor to seize the debtor, his family and even his property in the event of a loan default. In this circumstance, many small farmers forfeited their rights to property and opted to become permanent slaves in a strange exchange for their rights to freedom. This was the socio-economic milieu that generated such inhuman interpersonal relationships. Indirectly, the means of livelihood of the less privileged was in the hands of the upper class of the society who also controlled the political economy of the Eighth Century Judah.

In a systematic sequence, Yahweh through Isaiah confronts Judah in a very sharp polemic, equating them to Sodom and Gomorrah. These two typologies are imageries of everything that is bad from the pre-historical period. It therefore also sets the tone, theme and language of the passage as very blunt and direct. In addition, the indictments and expression of Yahweh's loathing of Judah's cultic practices show how fearless and courageous Isaiah was and also suggests his oracle as that of an insider of the royal court (Coogan, 2006).

However, there is a proportional imbalance in the allocation of verses to both the indictment (vs.10-15) and the solution (vs.16-17) as expressed by Isaiah, which is an equivalence of Mic.6: 6-8. In the typical poetic form and characteristic parallelism, Isaiah expresses vividly the evil and treachery perpetuated by Judah which was responsible for the blood in his hands and how to wash it clean by the close observation of the Sinai covenant (Bellinzoni, 2009). Again, the language in this passage is anthropomorphic describing Yahweh in human terms with sensory organs. In v.13, the smell of the incense is disgusting to Yahweh and in v.15 s/he/it hides the eyes when Judah spreads his hands in prayers, which will not be heard by his/her/its ears. Yahweh is also portrayed as one with a soul that hates violence in a holy assembly.

Basically, there seems to be no significant differences in various English versions of this passage in the BHS but there are some minor alterations capable of changing the meaning entirely, depending on the reader. For example, in V.15, the TNK substitutes 'blood' with 'crime', which encapsulate a multitude of misdeeds insofar as it is common knowledge that not all crimes involve blood shedding. In addition, different catch phrases have been employed in translating v.17c, but one would prefer the NKJV's 'rebuke the oppressors' because it confronts the problem. Others like 'make the oppressor happy' (YLT) seems to trivialize the magnitude of the problem, while TNK's version, 'aid the wrong' sounds a little off the beat.

\section{Issues}

One major issue in this paper is the remote connection between various contemporary meanings given to the words 'sacrifice' and 'blood' as 
representative of vicious oppression and their non-literary understanding as life respectively. For the most part while 'sacrifice' connotes something ritualistic, the word 'offering' has been commonly used interchangeably to describe an act of giving in the Judeo-Christian tradition. From another dimension, 'sacrifice' suggests self-denial that speaks again of giving or sharing even when it is inconvenient or uncomfortable for the giver. However, sacrifice in this context is for those who give with a pure heart (Is.1:16, Matt.5:23-24). The reason is that once their motive is corrupted or Yahweh finds it impure, all their efforts become futile and their prayers, unanswered (Ps.66:18).

In a way, this is what Isaiah refers to as 'your hands are full of blood'. Certainly, there is no direct reference to the metaphorical expression of blood in this passage that suggests more than human blood. Evidence abounds in the scripture which refers to child sacrifice, yet human blood here is an exaggeration resulting in an attempt by Isaiah to give a vivid description of what the oppressed suffer in the hands of the oppressor. From antiquity, blood represents life and life in itself is blood. Scientifically, biology shows how blood transports oxygen to all the parts of the body, failure of which can result in loss of life. Therefore, blood supplies life to the body mechanically, which is a testimony that there is life in the blood and blood keeps life going.

The point being made is that those who make life an added burden for the oppressed are squeezing blood out of them by the suffering they take them through and the pain that is inflicted on them. While R.E. Clements' assertion (1980) that the reference was to blood from animal sacrifice is contestable, it is also reasonable to accept that Isaiah talks about the suffering and misery brought to the oppressed by their oppressors. For as many as are mindless of the poor, disinheriting the orphans and disenfranchising the widows have their hands full of blood.

Further in this passage, ethical questions are raised and also answered by the poet-prophet. There were expectations in the community of different levels of social interaction that must conform with the religious injunctions of the Torah. From good neighborliness to the welfare of the less privileged - the alien, poor, orphan and the widow- the Torah is very clear about the duties of individuals whereby there are also penalties for failure to conform.

According to Childs (1998) and Hanson (2001), it has been difficult for scholars to structure this passage in form-critical distinctions. The reason is that all the three prominent features - priestly, prophetic and wisdom- are found in this passage that encompasses a blend of both the Exodus-Sinai and Levitical traditions (Brueggermann, 1998). Isaiah is blunt and bold as his suggestions are logical and commonsensical in the light of the existential dispensation of his time, which is also applicable to our post/modern era. 


\section{Application to the Contemporary Church and Society}

Etymologically speaking, the word 'Church', rooted in Greek language ekklesia as known today, is the aggregate of the militant, repentant and the triumphant realms in the body of Christ (Hendrix, 1994). It refers more to the body of Christian believers than a building meant for worship. This is also known as a holy assembly of a peculiar people "called out' under the lordship of Jesus Christ as the Head (Eph. 1:22-23). Paul the apostle referring to a body of believers says, "Greet the church that is in their house" (Rom. 16:5). The universal church therefore defines those who have placed their faith in Jesus Christ for their salvation, teaching, preaching, encouraging and building one another in his knowledge and grace while following his commandments to live in love (MacArthur, 2008). Moreover as a sign of commonality, they come together periodically in fellowship to lift up 'holy hands' in worship and offer sacrifices of praise and thanksgiving to the savior of their souls.

In sociology, a society is defined "as a group of individuals in persistent social interaction, a large social group sharing the same spatial or social territory, typically subject to the same political authority and dominant cultural expectations". For the purposes of this article, a society may be considered as a community of persons living and associating together in a kind of religious, social, benevolent, cultural, scientific, political, patriotic, or other bonds (Lenski, 1974; Jenkins, 2002). In other words, there should be a degree of interpersonal relationships and interdependency on individual and collective bases in order to foster unity, good neighborliness and mutual benefits for the promotion of peace and harmony.

From the foregoing, it is instructive to note that the components of the definitions above are not only interwoven, but also interconnected to the extent that there is just a thin line between what a church is and a society. A common factor that requires a closer look is the fact that both are consisting of individuals who are into socio-religious and political interpersonal relationships which are now under scrutiny. One fundamental truth is clear: and that is to live in love, peace and harmony requires a lot of sacrifice/selfdenial, then to give and take. Self-denial, as a form of acceptable sacrifice before Yahweh is key to Isaiah's message, like his contemporaries, and it emphasizes the alleviation of suffering and misery from the lives of fellow humans as a prerequisite.

In the light of the above definitions, relationships fuelled by sacrifice/self-denial become a common denominator. Similar to this assertion are the prerequisites to be met by Christian believers for eternal fellowship as explained by Jesus Christ, the head of the Church, in the gospel of Matthew 25: 31-46 explaining a figurative picture of the last judgment. The thrust of this message is that whoever does not care to be his brother's or her sister's keeper is not fit to partake in any form of fellowship at all. And this is in 
tandem with Isaiah's message that whatever happens to one concern all, otherwise any work, worship or service to Yahweh that does not take seriously the care for the widow, aliens and the less privileged is futile. In addition, this way of life fits with what was obtainable in the Early Church among the first apostles where everything was held in common and shared according to need and not greed (Acts 4:32-35).

The global scene today looks a replica of the Eighth Century Judah where Isaiah prophesied. In contemporary world politics, there is exploitation of the weak and poor nations by the strong, powerful and rich nations. Post colonization comes back in the form of globalization where manpower in poor nations is remunerated by the buoyant economic powers far below the generally acceptable standard. Ironically, the claim in this argument is that those underdeveloped nations are being assisted and supported to grow industrially while they are, indeed, also being exploited by the developed nations. World Trade Organization championed by American interests, World Bank and IMF are good examples of this description (Hopkins, 2002).

Essentially in every interaction, there are almost always varied and diametrically opposite interests at stake. Aiding the oppressed comes also in the form of loans whose terms of repayment are deliberately designed in such a way not only to elongate the suffering of the borrower-nations, but also postpones perpetually the ability to become economically independent and viable enough to pay. In other words, the concentration of the debtor-nations is always on the payment of interests accrued from unpaid loans leaving the principal for generations unborn to contend with. In fact, this is not really different from the ancient law of credit in the Eighth Century Judah. The result is that debtor-nations become political and economic annexes of creditornations who take over the 'failed' nations as regards various policies, who also in turn, are grateful for the guarantee of their right to freedom as slaves under their master.

If the people who worshipped Yahweh in Isaiah's time have been likened to Sodom and Gomorrah because they neither listened nor obeyed Him, this generation too cannot be excluded from the deeds that made God to compare them to those cities associated with doom. In the modern selfcentered society, many of those who are privileged, marginalize and oppress the less privileged at will and still come before Yahweh's altar to offer sacrifices with impunity. The outbreak of Covid 19 pandemic exposed some of these ills and a good example may be found in the health sector of some developing countries. Some African leaders, for instance according to Devermont (2020), have neglected building a strong health sector and most of the funds budgeted for this sector are diverted at will since they have the luxury of jetting out of their countries for medical attention oversees whenever the need arises. These leaders leaving the less privileged who find it difficult 
even to access good nutrition to their fate and to enrich themselves at the expense of poor is a very good example of Isaiah's cry in the nations of the world and in Africa in particular.

In the same vein when the place of worship and sacrifice are discussed as related to the time of Isaiah in the contemporary church, Lev. 10:1 comes to mind. "And Nadab and Abihu, the sons of Aaron, took either of them his censer, and put fire therein, and put incense thereon, and offered strange fire before the LORD, which he commanded them not." Essentially these were leaders of worship who just wanted to do it the easy way, their own way, not Yahweh's way. The result of their action is recorded in Lev. 10:2 "And there went out fire from the LORD, and devoured them, and they died before the $L O R D$. " In the spiritual realm, it is difficult to offer Yahweh what he disallows as sacrifice. Such sacrifices become strange once the hands brought them are stained by the blood of the innocent and whatever comes from those hands are displeasing and abominable to Yahweh.

By extension, greed and corruption in low and high places has contributed in no small measure to stain the hearts and hands of world leaders in the contemporary church and the society. Of course there is only a thin line between the church and the society because the church is an integral part of the larger society and at some point, the church itself can be defined as a society. In fact, some people see the church as a religious center for social interaction. In this domain, interpersonal relationships are expected to be filled with transparent love for one another and godly character which is also the hallmark of all Christian believers in every community. The Church and the society at large should have zero tolerance for bigotry, systemic racism, bribery and corruption, nepotism, hate, social injustice, inequality and other manners of evil now found in some nations of the world that were hitherto good examples for others to follow.

According to Dada "in Nigeria today, as in most African countries, poverty, distress, violence and corruption are ever present realities" (Dada, 2004) According to him prosperity gospel is probably an answer to the situation. The prosperity preachers believed that poverty is a sign of sickness that must be wiped out of the society. Positive confession is encouraged and sowing of seed of faith is one of the identities of such churches. It is necessary that the Church should re-visit the theology of prosperity again. It is good to be prosperous but the means and process should be without any doubt. This is very important because of the understanding or interpretation attached to the acquisition of wealth by all means is simply alarming. The early church showcases all the embodiments of godliness and dedication to the growth of every member of the church. If the contemporary church is fashioned along this line, then the rise in the number of Churches in our society should be 
commensurate with the fear of Yahweh reflecting godly living and contentment found among the people.

Perhaps it is pertinent to explicate Isaiah's conviction in this passage at an individual level from the perspective of some 'Pentecostal churches' in Africa. It is commonplace for government officials and businessmen to enrich themselves through corruption, exploitation and other injustices, out of which they pay tithes and offerings in compliance with the biblical injunction (Abogunrin, 1988). A nation cannot repent unless the individuals who are composite citizens of that nation repent. Ironically unlike Isaiah and other prophets of old, religious leaders in contemporary times look away as long as there is plenty in the house of God! A lot of people feel pious in their own eyes when they appear for liturgical worship even in this state of mind. There can be no reformation in the church unless the individuals who are the components of the church reform themselves individually.

\section{Conclusion}

Isaiah draws a vivid picture of the violent contrast between what men do in church and what they really are in daily life. It becomes apparent that no splendor of worship can compensate for a complete disregard of God's moral standard in social relationship. Men whose fortunes are built on crimes, - their eyes hot with lust and greed, and their hearts hardened against justice, their ears shut against the cry of little children and brokenhearted women - also appear before Yahweh for Holy Eucharist every Sunday with offerings in their hands and expect their prayers to be answered.

At this juncture, one should comfortably query the relationship between worship and social ethics and probe if religion has any bearing on character and moral conduct. Religious leaders who are passive in the face of evil are not only accomplices to crime - cruelties, injustices and sins of greed - but also equally as guilty as the political class who design these harsh and unfavorable conditions of living. Many have been frustrated by these socioeconomic policies to commit suicide while others have fallen into some other terrible predicaments.

That is the blood Isaiah talks about in this passage, with the presence of which worship remains meaningless and futile while Yahweh will also not listen to their prayers. It is indeed clear that this is a deep inconsistency between the faith we profess and the ethical standard to which we consent. Meaningful worship and acceptable sacrifice gives priority to social justice and anything short is an abomination to Yahweh.

As he concludes this passage in v.17, Isaiah suggests there is remedy to these evil doings in order that Yahweh may take cognizance of Judah's worship and sacrifice and thereby, answer the prayers of the people. His admonition is that people must seek justice by learning the law, striving always 
to do good, correcting the ills of the society, defending the poor, and pleading the cause of the orphans and widows. This is the summary of the positive steps the people of Yahweh are ordered to take especially in their own administration of justice as a reminder of the commandments of Yahweh given to them through Moses many centuries ago (Ex. 20:1-20). In church and the society at large, political and religious leaders are supposed to be the voice of the voiceless and the defender of the less privileged.

\section{References:}

1. Abdulkarim, Y. (2012) Socio-economic Effects of Judicial Corruption in Nigeria. International Journal of Humanities and Social Science Invention, 1(1), 31-36.

2. Abogunrin, S.O. (1988) "The Community of God in the Early Church and the Distribution of National Wealth", in African Journal of Biblical Studies, Vol.1, 74-94

3. Abogunrin, S.O. (ed) (2007) "Jesus Pronouncements on Wealth in the Context of Health and Wealth Gospel in Nigeria" in Biblical Studies and Corruption in Nigeria, Ibadan: M. Alofe Nigeria Enterprises, 274-278

4. Albertz, R. (1994) A History of Israelite Religion in the Old Testament Period Vol. I: From the Beginnings to the End of the Monarchy, Louisville, Ky: Westminster J. Knox Press, 159-161

5. Asamoah-Gyadu, J.K. (2005) African Charismatic: Current Development within Independent Indigenous Pentecostalism in Ghana (Leiden: Library of Congress cataloging in Publication Data), 201-202.

6. Aver, T. T., \& Orban, W. J. (2014) Judiciary and Democracy, Issues in Contemporary Nigerian Society. Global Journal of Arts, Humanities and Social Sciences, 2. (1), 85-95.

7. Ayodeji, G. I., \& Odukoya, S. I., (2014) Perception of Judicial Corruption: Assessing its Implications for Democratic Consolidation and Sustainable Development in Nigeria. Journal of Sustainable Development in Africa, 16 (2), 67-80.

8. Bellinzoni, Arthur J. (2009) The Old Testament: An Introduction to Biblical Scholarship, NY: Prometheus Books, 90-92

9. Brueggemann, W. (1998) Isaiah 1-39, Louisville, Ky: Westminster J. Knox Press, 17-19

10. Childs, B.S. (1998) Isaiah, Louisville, Ky: Westminster John Knox Press, 19-20

11. Clements, R.E. (1980) The New Century Bible Commentary: Isaiah 139, Marshall, Morgan \& Scott Ltd., 33

12. Coogan, M.D. (2006) The Old Testament - A Historical and Literary Introduction to the Hebrew Scriptures, NY: Oxford University Press, 330-332 
13. Dada, O.A. (2004) "Prosperity Gospel in Nigerian Context: A Medium of Social Transformation or An Impetus for Delusion? Orita: Ibadan Journal of Religious Studies xxxvi/1-2 96

14. Devermont, Judd (2020) "A Seat at the Table: African Leadership in a Post-COVID-19 World" in On the Horizon Washington: Center for Strategic and International Studies

15. Emerton, John A. (1993) "The Historical Background of Isaiah 1:4-9," ErIs 24

16. Fishbane, M. (2002) Haftarot: The Traditional Hebrew Text with the New JPS Translation [and] Commentary, JPSBC; Philadelphia: Jewish Publication Society, 270-71, 485 n. 5

17. Gitay, Yehoshua (1983) "Reflections on the Study of Prophetic Discourse: The Question of Isaiah I 2-20," VT 33 207-21; idem, Isaiah and His Audience, 14-34

18. Hanson, P.D. (2001) The People Called: The Growth of Community in the Bible, Louisville, Ky: Westminster J. Knox Press, 181-185

19. Hendrix, Scott H. (1974). Ecclesia in Via. Brill Archive. 225

20. Holladay, William L. (2002) Unbound by Time - Isaiah Still Speaks, Cambridge: Cowley Publications, 34-36

21. Hopkins, D.N. (2002) Heart and Head: Black Theology-Past, Present, and Future, NY: Palgrave, 130-140

22. Jenkins, Richard (2002). Foundations of Sociology. London: Palgrave MacMillan.

23. Lenski, Gerhard E. (1974). Human Societies: An Introduction to Macrosociology. New York: McGraw-Hill, Inc.

24. Lewis, Charlton T.; Short, Charles, eds. (1879). "dǒlěo". A Latin Dictionary. Oxford: Clarendon Press. Archived from the original on 4 September 2018. Retrieved 1 July 2016.

25. MacArthur, John (2008). The Master's Plan for the Church, Chicago: Moody Publishers

26. Newsome Jr., J. D., (1984) The Hebrew Prophets, Louisville, Ky: Westminster J. Knox Press, 17-40

27. Ogbu, O. N. (2011) Political Will and War against Corruption. The National Scholars, 8(1), 24-29.

28. Ogunye, J. (2011) A New Nigerian Judiciary is Necessary. Sahara Reporters Commentary, October 3, 2011 - 14:29.

29. Okeyim, M. O., Ejue B. J., \& Ekanem, S. A. (2013) Governance and corruption in Nigeria: A Philopsychological Analysis. Net Journal of Social Sciences, 1(2), 24-32.

30. Osuji, C. (2012) Rubrics of thought: Using judiciary to kill democracy in Nigeria: Fact: Daily Independent Newspapers. 
31. Owoeye, S.A. (2000) "Solution to Poverty: Oyedepo's Prophetic and Healing Mission in Nigeria" in Journal of Religion and African Culture Vol. 1\& 2: Adekunle Ajasin University, Akungba-Akoko, Nigeria

32. Roberts, J. J. M. (1982) "Form, Syntax, and Redaction in Isaiah 1:2-20," PSB 3 293-306

33. Seltzer, R. M. (1980) Jewish People, Jewish Thought: The Jewish Experience in History, NY: Macmillan Publishing Co. Inc., 86-87

34. The Holy Bible - Revised Standard Version

35. Tomasino, A. J. (1996) 'Isaiah 1.1-2.4 and 63-66, and the Composition of the Isaiah Corpus' in "The Prophets" ed. P.R. Davies, Sheffield: Sheffield Academic Press, 152-154

36. Wendland, Ernst (1994) "Discourse Analysis of Hebrew Poetry," Perspectives on Hebrew Poetry in the Scriptures ed. Ernst R. Wendland; UBSMS 7; New York: United Bible Societies, 1-27; 1516

37. Willis, John T. (1984) "The First Pericope in the Book of Isaiah," VT 34 63-77

38. Zvi, Ehud Ben (2000) Micah (FOTL 21B), Grand Rapids: Eerdmans 